\title{
Diabetes and Thyroid Cancer Risk: Literature Review
}

\author{
Shyang-Rong Shih, ${ }^{1,2}$ Wei-Yih Chiu, ${ }^{1,2}$ Tien-Chun Chang, ${ }^{1,2}$ and Chin-Hsiao Tseng ${ }^{1}$ \\ ${ }^{1}$ Department of Internal Medicine, National Taiwan University Hospital, No. 7, Chung Shan South Road, Taipei 10002, Taiwan \\ ${ }^{2}$ National Taiwan University College of Medicine, Taipei, Taiwan
}

Correspondence should be addressed to Chin-Hsiao Tseng, ccktsh@ms6.hinet.net

Received 30 January 2012; Revised 30 March 2012; Accepted 20 April 2012

Academic Editor: Chien-Jen Chen

Copyright (C) 2012 Shyang-Rong Shih et al. This is an open access article distributed under the Creative Commons Attribution License, which permits unrestricted use, distribution, and reproduction in any medium, provided the original work is properly cited.

Diabetic patients have a higher risk of various types of cancer. However, whether diabetes may increase the risk of thyroid cancer has not been extensively studied. This paper reviews and summarizes the current literature studying the relationship between diabetes mellitus and thyroid cancer, and the possible mechanisms linking such an association. Epidemiologic studies showed significant or nonsignificant increases in thyroid cancer risk in diabetic women and nonsignificant increase or no change in thyroid cancer risk in diabetic men. A recent pooled analysis, including 5 prospective studies from the USA, showed that the summary hazard ratio (95\% confidence interval) for women was $1.19(0.84-1.69)$ and was $0.96(0.65-1.42)$ for men. Therefore, the results are controversial and the association between diabetes and thyroid cancer is probably weak. Further studies are necessary to confirm their relationship. Proposed mechanisms for such a possible link between diabetes and thyroid cancer include elevated levels of thyroid-stimulating hormone, insulin, glucose and triglycerides, insulin resistance, obesity, vitamin D deficiency, and antidiabetic medications such as insulin or sulfonylureas.

\section{Introduction}

During the past several decades, the prevalence of diabetes has markedly increased [1-3]. Diabetes is associated with increased risk of various kinds of cancer, such as colon cancer, pancreatic cancer, breast cancer, bladder cancer, prostate cancer, and non-Hodgkin's lymphoma [4-8]. Meanwhile, the incidence of thyroid cancer is rising at a rate that is among the fastest of all malignancies [9]. According to a survey in the United States, the incidence of thyroid cancer increased by 2.4 -fold from 1973 to 2002 , and $87 \%$ of the increase consisted of cancers measuring $2 \mathrm{~cm}$ or smaller, but the mortality from thyroid cancer was stable [10]. It is believed that the major cause of this increase in incidence is the enhanced detection of early-stage tumors by the use of thyroid ultrasound and ultrasound-guided fine needle aspiration cytology examination. However, this cannot explain the increased prevalence preceding the widespread use of ultrasound [11]. It also cannot explain the increased incidence of large $(>5 \mathrm{~cm})$ papillary thyroid cancer [12]. Therefore, there may be some other contributing factors of the increased incidence of thyroid cancer. According to epidemiologic studies, exposure to ionizing radiation is the only clearly established risk factor [13]. Benign thyroid conditions and inadequate or excess iodine intake are the possible risk factors of thyroid cancer [13]. None of them can explain the increased thyroid cancer incidence. Statistic analysis showed that diabetes, obesity, and metabolic syndrome were potential risk factors of cancer development [14-16]. It is not clear whether diabetes plays a role in thyroid cancer risk. In this paper, we review the literature reporting the relationship between diabetes mellitus and thyroid cancer (summarized in Table 1) and the proposed mechanisms linking such an association (depicted in Figure 1).

\section{Epidemiologic Findings}

The prevalence of thyroid disorders among diabetics (10.8\%) is higher than that in the general population (6.6\%) [24]. Several studies disclosed the relationship between diabetes and thyroid cancer (Table 1) $[13,17,18,20-23]$. Study 
TABLE 1: Summary of available studies evaluating the relationships between diabetes and thyroid cancer.

\begin{tabular}{|c|c|c|c|c|c|c|}
\hline $\begin{array}{l}\text { Study no. } \\
\text { [reference] }\end{array}$ & Year author & Country & Name of study & Study design & $\begin{array}{l}\text { Number of cases/ } \\
\text { Follow-up duration }\end{array}$ & Estimated risk \\
\hline $1[17]$ & 1991 Adami et al. & Sweden & $\begin{array}{l}\text { Cancer risk in } \\
\text { patients with } \\
\text { diabetes mellitus }\end{array}$ & $\begin{array}{l}\text { Population-based } \\
\text { cohort study }\end{array}$ & $\begin{array}{l}\text { 51,008 patients. Cohort } \\
\text { established by } \\
\text { identifying diabetic } \\
\text { patients during } \\
\text { 1965-1983. Complete } \\
\text { followup through } 1984\end{array}$ & $\begin{array}{l}\text { Women: } \mathrm{RR}=1 \\
\text { (95\% CI: } 0.6-1.8) \\
\text { Men: RR }=1.3 \\
(95 \% \text { CI: } 0.5-2.8)\end{array}$ \\
\hline $2[18]$ & 1997 Wideroff et al. & Denmark & $\begin{array}{l}\text { Cancer incidence } \\
\text { in a } \\
\text { population-based } \\
\text { cohort of patients } \\
\text { hospitalized with } \\
\text { diabetes mellitus } \\
\text { in Denmark } \\
\end{array}$ & $\begin{array}{l}\text { Prospective cohort } \\
\text { study }\end{array}$ & $\begin{array}{l}\text { 109,581 diabetics. } \\
\text { Cohort established by } \\
\text { identifying diabetic } \\
\text { patients during } \\
\text { 1977-1989. Cohort exit } \\
\text { date: date of death or } \\
1993\end{array}$ & $\begin{array}{l}\text { Women: SIR = } 1.3 \\
(95 \% \text { CI: } 0.6-2.3) \\
\text { Men: SIR }=1.2 \\
(95 \% \text { CI: } 0.7-1.8)\end{array}$ \\
\hline $3[19]$ & 2006 Inoue et al. & Japan & $\begin{array}{l}\text { The Japan Public } \\
\text { Health } \\
\text { Center-based } \\
\text { Prospective Study }\end{array}$ & $\begin{array}{l}\text { Prospective cohort } \\
\text { study }\end{array}$ & $\begin{array}{l}46,548 \text { women, } 51,223 \\
\text { men } \\
\text { Followed from } 1990 \\
\text { through } 2003\end{array}$ & $\begin{array}{l}\text { Women: } \mathrm{HR}=1.11 \\
(95 \% \text { CI: } 0.35-3.5) \\
\text { Men: NA }\end{array}$ \\
\hline $4[20]$ & 2007 Kuriki et al. & Japan & $\begin{array}{l}\text { Hospital based } \\
\text { Epidemiologic } \\
\text { Research } \\
\text { Program at Aichi } \\
\text { Cancer Center, } \\
\text { Japan }\end{array}$ & Case-control study & $\begin{array}{c}\text { 11,672 incident cancer } \\
\text { cases } \\
\text { (5341 men, } 6331 \\
\text { women }) \\
47,768 \text { cancer-free } \\
\text { controls (14,199 men, } \\
\text { 33,569 women) }\end{array}$ & $\begin{array}{l}\text { Women: OR }=0.67 \\
(95 \% \text { CI: } 0.21-2.10) \\
\text { Men: OR }=1.07 \\
(95 \% \text { CI: } 0.33-3.48)\end{array}$ \\
\hline $5[13]$ & 2010 Meinhold et al. & USA & $\begin{array}{l}\text { The US } \\
\text { Radiologic } \\
\text { Technologists } \\
\text { Study } \\
\end{array}$ & $\begin{array}{l}\text { Prospective cohort } \\
\text { study }\end{array}$ & $\begin{array}{l}\text { 69,506 women, } 21,207 \\
\text { men } \\
\text { Followed from } 1983 \\
\text { through } 2006\end{array}$ & $\begin{array}{c}\text { Women: } \mathrm{HR}=1.37 \\
(95 \% \text { CI: } 0.49-3.77) \\
\text { Men: NA }\end{array}$ \\
\hline $6[21]$ & 2010 Chodick et al. & Israel & $\begin{array}{l}\text { Diabetes and risk } \\
\text { of incident } \\
\text { cancer: a large } \\
\text { population-based } \\
\text { cohort study in } \\
\text { Israel }\end{array}$ & $\begin{array}{l}\text { Retrospective cohort } \\
\text { study }\end{array}$ & $\begin{array}{c}\text { 16,721 DM, } 83,874 \\
\text { non-DM } \\
\text { Mean follow-up time: } 8 \\
\text { years }\end{array}$ & $\begin{array}{c}\text { Women: } \mathrm{HR}=1.61 \\
(95 \% \text { CI: } 0.96-2.69) \\
\text { Men: HR }=0.72 \\
(95 \% \text { CI: } 0.25-2.04)\end{array}$ \\
\hline 7 [22] & $\begin{array}{l}2011 \\
\text { Aschebrook-Kilfoy } \\
\text { et al. }\end{array}$ & USA & $\begin{array}{l}\text { The NIH-AARP } \\
\text { Diet and Health } \\
\text { Study }\end{array}$ & $\begin{array}{l}\text { Prospective cohort } \\
\text { study }\end{array}$ & $\begin{array}{c}\text { 200,556 women, 295,992 } \\
\text { men } \\
\text { Mean follow-up time: } 10 \\
\text { years }\end{array}$ & $\begin{array}{c}\text { Women: } \mathrm{HR}=1.54 \\
(95 \% \text { CI: } 1.08-2.20) \\
\text { Men: HR }=1.11 \\
(95 \% \text { CI: } 0.74-1.66)\end{array}$ \\
\hline $8[23]$ & 2012 Kitahara et al. & USA & $\begin{array}{l}\text { Physical activity, } \\
\text { diabetes, and } \\
\text { thyroid cancer } \\
\text { risk: a pooled } \\
\text { analysis of five } \\
\text { prospective } \\
\text { studies }\end{array}$ & $\begin{array}{c}\text { Pooled analysis of five } \\
\text { prospective studies, } \\
\text { including NIHAARP } \\
\text { Diet and Health Study } \\
\text { (NIH-AARP), Prostate, } \\
\text { Lung, Colorectal, and } \\
\text { Ovarian Cancer } \\
\text { Screening Trial } \\
\text { (PLCO), Breast Cancer } \\
\text { Detection and } \\
\text { Demonstration Project } \\
\text { (BCDDP), Agricultural } \\
\text { Health Study (AHS), } \\
\text { and US Radiologic } \\
\text { Technologists Study } \\
\text { (USRT) }\end{array}$ & $\begin{array}{l}\text { 312,149 women, } 362,342 \\
\text { men } \\
\text { Median follow-up time: } \\
10.5 \text { years }\end{array}$ & $\begin{array}{c}\text { Women: } \mathrm{HR}=1.19 \\
(95 \% \text { CI: } 0.84-1.69) \\
\text { Men: HR }=0.96 \\
(95 \% \text { CI: } 0.65-1.42)\end{array}$ \\
\hline
\end{tabular}




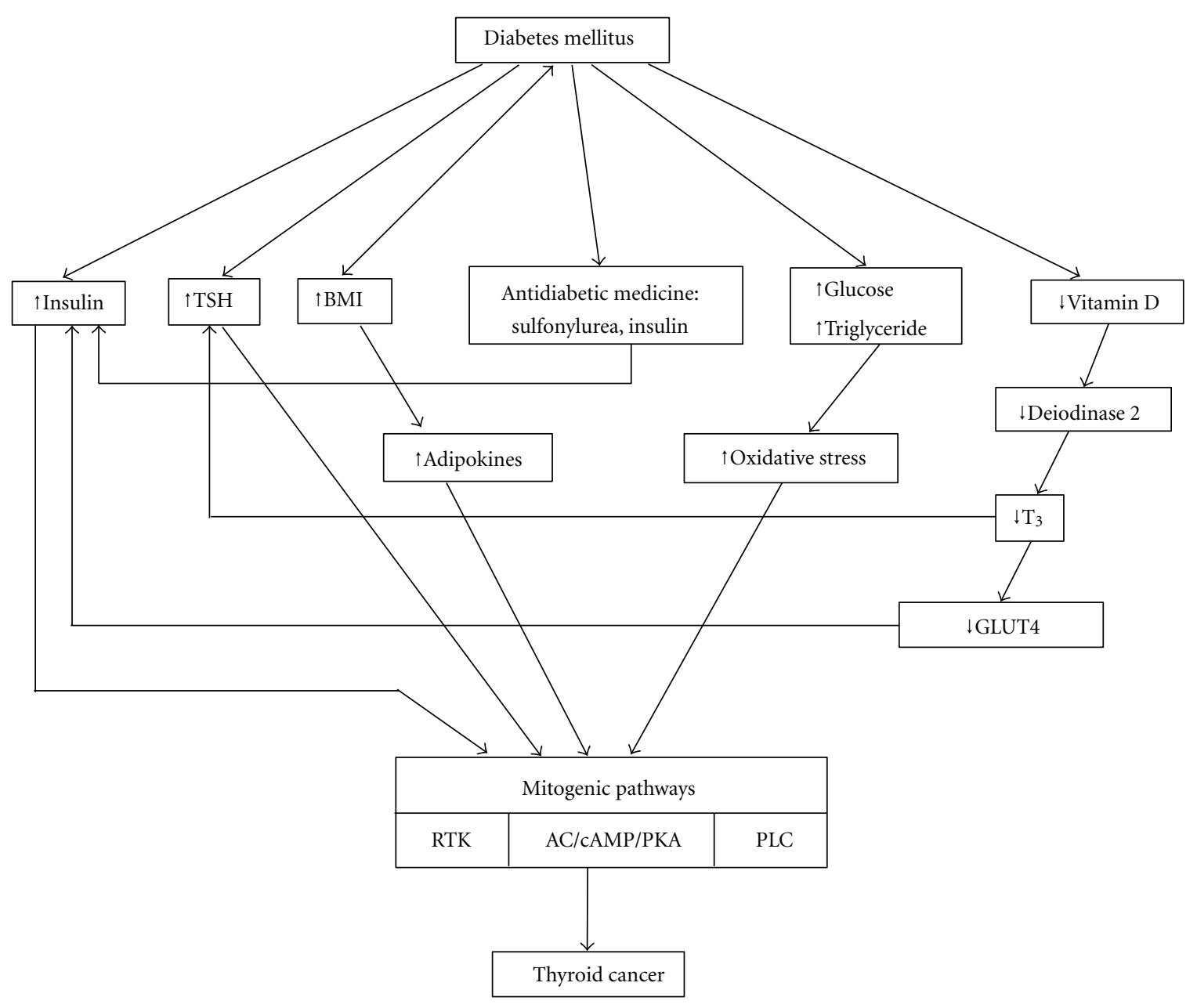

AC/cAMP/PKA: the hormone receptor adenylate cyclase cAMP protein kinase A system

BMI: Body mass index

GLUT4: Glucose transporter 4

PLC: The hormone receptor phospholipase $\mathrm{C}$ cascade pathway

RTK: The hormone receptor tyrosine protein kinase pathways

$\mathrm{T}_{3}$ : Triiodothyronine

TSH: Thyroid-stimulating hormone

Figure 1: Pathophysiology proposed to link diabetes and thyroid cancer together. Diabetes mellitus may affect mitogenic pathway of the follicular cells through several mechanisms. Increased insulin amount stimulates follicular cells because of its structural similarity to insulinlike growth factor. Increased TSH stimulated AC/cAMP/PKA pathway. Increased body mass index will increase adipokines and subsequently stimulate mitogenic pathways. Antidiabetic medicines of sulfonylurea and insulin contribute to the elevated insulin level. Hyperglycemia and hypertriglycemia increase oxidative stress and stimulate mitogenic pathway. Vitamin D deficiency decreases deiodinase 2, $\mathrm{T}_{3}$ and GLUT4 transcription, which subsequently increase TSH and insulin levels and activate mitogenic pathways.

number 8 [23] in Table 1 is a pooled analysis including 5 prospective studies from the USA, which included studies numbered 5 [13] and 7 [22]. Significant or nonsignificant increases in thyroid cancer risk were observed in diabetic women $[13,18,19]$. Nonsignificant increases or no change in thyroid cancer risk were observed in diabetic men $[13,17,18,20]$. The results are controversial, and the link between diabetes and thyroid cancer is probably weak.

\section{Hypotheses Proposed to Link Diabetes to Thyroid Cancer Risk}

Currently, there are some hypotheses linking diabetes to thyroid cancer risk, including (i) increased body mass index (BMI); (ii) elevated insulin levels; (iii) long-term elevation of thyroid-stimulating hormone (TSH); (iv) longterm exposure to high levels of glucose and triglycerides; (v) vitamin D deficiency; (vi) use of antidiabetic medications 
including insulin and sulfonylureas [22] (Figure 1). There are some epidemiological studies demonstrating the relationships between thyroid cancer and BMI, TSH, blood glucose, and triglycerides.

3.1. Molecular Pathogenesis of Thyroid Cancer. In normal adults, the weight and composition of the thyroid glands remain generally constant [25]. The cells turnover about 6-8 renewals in adult life [25]. The cell growth is closely regulated by paracrine function of follicular cells, which secrete factors such as insulin-like growth factor I (IGF-1) and fibroblast growth factor to control other cells [26].

In thyroid glands, three distinct mitogenic pathways have been proposed: (i) the hormone receptor adenylate cyclase-cAMP protein kinase A system (AC/cAMP/PKA); (ii) the hormone receptor tyrosine protein kinase (RTK) pathways; (iii) hormone receptor phospholipase $\mathrm{C}$ cascade (PLC) pathway [27]. TSH is the major stimulator of the AC/cAMP/PKA pathway by binding to the TSH receptor (TSHR). This pathway regulates the function, differentiation, and proliferation of the thyroid glands [28]. Epidermal growth factor (EGF) stimulates RTK pathway, which leads to an increase in transcriptional activity [29]. The PLC pathway is activated by TSH, neurotransmitters, growth factors, and phorbol ester. This pathway subsequently increases the intracellular calcium and protein kinase C activity [30]. There are two models of thyroid carcinogenesis: fetal cell carcinogenesis theory and multistep carcinogenesis theory [27]. Factors affecting the mitogenic pathways may be involved in the pathogenesis of thyroid cancer.

Molecular pathogenesis involves genetic events [31]. Activating point mutations of the RAS genes is frequently found in follicular thyroid carcinomas [31]. Rearrangements of genes (RET, TKR) of transmembrane receptors with tyrosine kinase activity and activating point mutations of the $B R A F$ gene are found in papillary thyroid carcinomas [31]. Poorly differentiated and anaplastic thyroid carcinomas are found to have inactivating point mutations of the P53 gene [31]. Mutations of RET oncogene may also be responsible for the tumorigenesis of medullary thyroid cancer [31].

3.2. Elevated Insulin Levels and Thyroid Cancer Risk. Chronic elevated circulating insulin level is observed in diabetics and may be due to endogenous (insulin-resistance-related) or exogenous sources (medications). Insulin shares structural homology and affinity of the receptors with IGF-1, and is important for cell proliferation and apoptosis [32]. Elevated insulin and IGF-1 levels are related to various cancers, such as breast and colon cancers [33,34]. As mentioned above, IGF-1 may control follicular cell growth [26]. In follicular cell cultures, incubation of follicular cells with TSH and insulin causes significant increase in cell number than incubation with TSH alone [35], suggesting that insulin may mimic IGF-1 in follicular cells. Follicular cells do synthesize IGF1 and have IGF- 1 receptors, which is associated with the pathogenesis of thyroid nodules by potentiating TSH action [36]. Therefore, insulin may also play a role in thyroid carcinogenesis. Some studies demonstrated the association between insulin resistance and thyroid nodules and thyroid cancer [37, 38]. However, to our knowledge, there has been no human study directly confirming the association between insulin exposure and thyroid cancer.

3.3. TSH and Thyroid Cancer Risk. As mentioned above, TSH is involved in mitogenic pathways of the thyroid glands [27]. TSH is an independent risk factor of thyroid cancer development [39-41]. Thyroid cancer risk increases with higher TSH level [40]. Higher TSH level is also associated with advanced stage of differentiated thyroid cancer [40]. Diabetic patients are more prone to have chronically mild TSH elevation. Previous study showed that $3 \%$ of insulindependent diabetics had hypothyroidism, and $13-20 \%$ had elevated TSH levels and antithyroid antibodies [42]. A recent study showed that the rate of primary hypothyroidism in type 2 diabetics is greater than in the nondiabetic population (odds ratio $=3.45 ; 95 \%$ CI: 2.51-4.79) [43]. The increased thyroid cancer risk may be related to the elevated TSH level in diabetic patients.

3.4. Increased BMI and Thyroid Cancer Risk. Obesity is associated with several types of cancer, such as adenocarcinoma of the esophagus, colon, kidney, endometrium, and malignant melanoma [44]. Obese people are at a 10-fold increased risk of diabetes [45]; and they may have increased risk of thyroid cancer [22, 46, 47]. Adjustment for BMI slightly reduced thyroid cancer risk associated with diabetes, but BMI only could not explain the association between diabetes and thyroid cancer [22]. Meta-analysis showed that an increase in BMI of $5 \mathrm{~kg} / \mathrm{m}^{2}$ was associated with an increased risk of thyroid cancer in both men $(\mathrm{RR}=1.33$; $P=0.02)$ and women $(\mathrm{RR}=1.14 ; P=0.001)$ [47].

Potential mechanisms linking obesity and thyroid cancer risk include elevated TSH levels, insulin resistance, and adipokines effect $[9,46]$. Some studies showed that BMI and TSH levels were positively correlated, but others did not [46]. As mentioned above, TSH and insulin influence the growth and differentiation of follicular cells [27]. Adipokines such as adiponectin, leptin, and hepatocyte growth factor may regulate cancer cell proliferation and may be related to cancer progression [9]. Increased expression of leptin and its receptor in thyroid cancer were reported [48]. Its association with tumor aggressiveness and biological behavior was also demonstrated [48]. However, an inverse association was identified between BMI and tumor invasion and nodal metastasis in a clinicopathological cohort study [9]. Further study is necessary to determine the relationship between BMI and thyroid cancer outcome.

3.5. Antidiabetic Medications and Thyroid Cancer Risk. According to previous studies, cancer risk in metformintreated patients is similar to that in patients not receiving medication for diabetes [49]. Metformin diminishes growth stimulation by insulin and inhibits growth of thyroid cancer in vitro [50]. There are several mechanisms proposed for the antitumor effect of metformin such as increasing the 
AMP-activated protein kinase signaling pathway and a direct influence upon immune competence [51].

Sulfonylureas are associated with increased mortality $(\mathrm{HR}=1.3 ; 95 \% \mathrm{CI}: 1.1-1.6)$ [52]. Cancer mortality is about doubled among insulin users relative to metformin users $(\mathrm{HR}=1.9 ; 95 \%$ CI: 1.5-2.4) [52]. Cancer risk increases by an estimated $20 \%$ for each year of insulin therapy [53]. Increased circulating insulin level may be another explanation for the increased cancer risk associated with sulfonylureas and insulin therapy [51]. As mentioned above, high insulin levels and the associated changes of the IGF-1 axis may be associated with cancer development. Glargine, a long-acting insulin analog, may have even higher cancer risks compared with human insulin [51]. This is possibly due to the prolonged binding of IGF-1 receptor, leading to increased mitotic activity [51]. To our knowledge, there has been no human study confirming the association between insulin and sulfonylurea treatment and thyroid cancer [22].

The association of incretin-based therapy and medullary thyroid cancer had been widely discussed. Glucagon-like pepide-1 receptor activation promotes C-cell proliferation and medullary thyroid cancer in rodents $[54,55]$. Currently, there is no sufficient data to confirm the association between incretin-based therapies and thyroid cancer in humans [56].

Other potential drugs are peroxisome proliferatoractivated receptors (PPARs) $\gamma$ agonists, which has been demonstrated to promote the growth and invasion of thyroid cancer cells in vitro with an increase in G1 phase and a decrease in the $S$ and G2/M phases [57]. But the mechanism is unclear.

3.6. Chronic Glucose and Triglycerides Exposure and Thyroid Cancer Risk. Studies showed that men with elevated level of triglycerides and women with increased blood glucose level were more prone to have thyroid cancer $[14,58,59]$. The possible mechanism is the increased oxidative stress. Free fatty acids and glucose stimulate nuclear factor- $\kappa$ B, which increases the production of nitric oxide, a substrate for reactive oxygen species (ROS) [60]. Low level of ROS regulates cellular signaling and is important in normal cell proliferation. Increased ROS is observed in cancer cells [14]. However, a recent large-scale cohort analysis shows that glucose was inversely associated with thyroid cancer risk in women below 50 years old, was not related to thyroid cancer risk in women above 50 years old, and was associated with an increased thyroid cancer risk in men [61]. The proposed mechanism is the complex relationship among reproductive hormones, glucose, and thyroid cancer. Since the study lacks detailed information on reproductive history and sex hormone use, it cannot come to any conclusion. In summary, current human studies showed controversial relationship between glucose level and thyroid cancer risk.

3.7. Vitamin D Deficiency and Thyroid Cancer Risk. Vitamin $\mathrm{D}$ deficiency is observed in up to $70 \%$ of diabetics, although the reason is unclear $[22,62]$. Vitamin D promotes differentiation and apoptosis of cancer cells [63]. Low vitamin D level decreases deiodinase 2, resulting in decreased intracellular triiodothyronine $\left(\mathrm{T}_{3}\right)$ [22]. Decreased $\mathrm{T}_{3}$ concentration in skeletal muscle and adipose tissue should lead to decreased glucose transporter 4 transcription and thus lead to insulin resistance [22]. Decreased $\mathrm{T}_{3}$ concentration in pituitary gland stimulates TSH release [22]. As mentioned above, insulin resistance and TSH may be related to thyroid cancer. To our knowledge, there has been no human study directly confirming the association between vitamin D deficiency and thyroid cancer.

\section{Conclusion}

Epidemiologic studies showed significant or nonsignificant increases in thyroid cancer risk in diabetic women, and nonsignificant increases or no change in thyroid cancer risk in diabetic men. The results are controversial, and evidence is not strong enough to link diabetes and thyroid cancer. Mechanisms proposed to link diabetes and thyroid cancer include elevated TSH, insulin, glucose, triglycerides, insulin resistance, obesity, vitamin $\mathrm{D}$ deficiency, and antidiabetic medications. However, these mechanisms are mostly postulated from epidemiological studies, and studies providing direct biological modes of action are still scarce. Further research is necessary to confirm the relationship between diabetes and thyroid cancer and to explore the underlying mechanisms.

\section{References}

[1] I. B. Ahluwalia, K. A. Mack, W. Murphy, A. H. Mokdad, and V. S. Bales, "State-specific prevalence of selected chronic disease-related characteristics-behavioral risk factor surveillance system, 2001," Morbidity and Mortality Weekly Report Surveillance Summaries, vol. 52, no. 8, pp. 1-80, 2003.

[2] A. A. Tahrani, C. J. Bailey, S. Del Prato, and A. H. Barnett, "Management of type 2 diabetes: new and future developments in treatment," The Lancet, vol. 378, no. 9786, pp. 182197, 2011.

[3] C. H. Tseng, C. P. Tseng, C. K. Chong et al., "Increasing incidence of diagnosed type 2 diabetes in Taiwan: analysis of data from a national cohort," Diabetologia, vol. 49, no. 8, pp. 1755-1760, 2006.

[4] S. S. Coughlin, E. E. Calle, L. R. Teras, J. Petrelli, and M. J. Thun, "Diabetes mellitus as a predictor of cancer mortality in a large cohort of US adults," American Journal of Epidemiology, vol. 159, no. 12, pp. 1160-1167, 2004.

[5] C. H. Tseng, C. K. Chong, and T. Y. Tai, "Secular trend for mortality from breast cancer and the association between diabetes and breast cancer in Taiwan between 1995 and 2006," Diabetologia, vol. 52, no. 2, pp. 240-246, 2009.

[6] C. H. Tseng, "Diabetes and risk of prostate cancer: a study using the National Health Insurance," Diabetes Care, vol. 34, no. 3, pp. 616-621, 2011.

[7] C. H. Tseng, "Diabetes and risk of bladder cancer: a study using the National Health Insurance database in Taiwan," Diabetologia, vol. 54, no. 8, pp. 2009-2015, 2011.

[8] C. H. Tseng, "Diabetes and non-Hodgkin's lymphoma: analyses of prevalence and annual incidence in 2005 using the National Health Insurance database in Taiwan," Annals of Oncology, vol. 23, no. 1, Article ID mdr334, pp. 153-158, 2012. 
[9] J. E. Paes, K. Hua, R. Nagy, R. T. Kloos, D. Jarjoura, and M. D. Ringel, "The relationship between body mass index and thyroid cancer pathology features and outcomes: a clinicopathological cohort study," The Journal of Clinical Endocrinology \& Metabolism, vol. 95, no. 9, pp. 4244-4250, 2010.

[10] L. Davies and H. G. Welch, "Increasing incidence of thyroid cancer in the United States, 1973-2002," The Journal of the American Medical Association, vol. 295, no. 18, pp. 2164-2167, 2006.

[11] M. T. Rojeski and H. Gharib, "Nodular thyroid disease. Evaluation and management," The New England Journal of Medicine, vol. 313, no. 7, pp. 428-436, 1985.

[12] L. Enewold, K. Zhu, E. Ron et al., "Rising thyroid cancer incidence in the United States by demographic and tumor characteristics, 1980-2005," Cancer Epidemiology Biomarkers and Prevention, vol. 18, no. 3, pp. 784-791, 2009.

[13] C. L. Meinhold, E. Ron, S. J. Schonfeld et al., "Nonradiation risk factors for thyroid cancer in the US radiologic technologists study," American Journal of Epidemiology, vol. 171, no. 2, pp. 242-252, 2010.

[14] W. Borena, T. Stocks, H. Jonsson et al., "Serum triglycerides and cancer risk in the metabolic syndrome and cancer (MeCan) collaborative study," Cancer Causes and Control, vol. 22, no. 2, pp. 291-299, 2011.

[15] I. R. Hsu, S. P. Kim, M. Kabir, and R. N. Bergman, "Metabolic syndrome, hyperinsulinemia, and cancer," The American Journal of Clinical Nutrition, vol. 86, no. 3, pp. 867S-871S, 2007.

[16] K. Y. Wolin, K. Carson, and G. A. Colditz, "Obesity and cancer," The Oncologist, vol. 15, no. 6, pp. 556-565, 2010.

[17] H. O. Adami, J. McLaughlin, A. Ekbom et al., "Cancer risk in patients with diabetes mellitus," Cancer Causes and Control, vol. 2, no. 5, pp. 307-314, 1991.

[18] L. Wideroff, G. Gridley, L. Mellemkjaer et al., "Cancer incidence in a population-based cohort of patients hospitalized with diabetes mellitus in Denmark," Journal of the National Cancer Institute, vol. 89, no. 18, pp. 1360-1365, 1997.

[19] M. Inoue, M. Iwasaki, T. Otani, S. Sasazuki, M. Noda, and S. Tsugane, "Diabetes mellitus and the risk of cancer: results from a large-scale population-based cohort study in Japan," Archives of Internal Medicine, vol. 166, no. 17, pp. 1871-1877, 2006.

[20] K. Kuriki, K. Hirose, and K. Tajima, "Diabetes and cancer risk for all and specific sites among Japanese men and women," European Journal of Cancer Prevention, vol. 16, no. 1, pp. 8389, 2007.

[21] G. Chodick, A. D. Heymann, L. Rosenmann et al., "Diabetes and risk of incident cancer: a large population-based cohort study in Israel," Cancer Causes and Control, vol. 21, no. 6, pp. 879-887, 2010.

[22] B. Aschebrook-Kilfoy, M. M. Sabra, A. Brenner et al., "Diabetes and thyroid cancer risk in the National Institutes of Health-AARP Diet and Health study," Thyroid, vol. 21, no. 9, pp. 957-963, 2011.

[23] C. M. Kitahara, E. A. Platz, L. E. Beane Freeman et al., "Physical activity, diabetes, and thyroid cancer risk: a pooled analysis of five prospective studies," Cancer Causes and Control, vol. 23, no. 3, pp. 463-471, 2012.

[24] P. Wu, "Thyroid disorders and diabetes. It is common for a person to be affected by both thyroid disease and diabetes," Diabetes Self-Management, vol. 24, no. 5, pp. 80-87, 2007.

[25] J. Coclet, F. Foureau, P. Ketelbant, P. Galand, and J. E. Dumont, "Cell population kinetics in dog and human adult thyroid," Clinical Endocrinology, vol. 31, no. 6, pp. 655-665, 1989.
[26] J. E. Dumont, C. Maenhaut, I. Pirson, M. Baptist, and P. P. Roger, "Growth factors controlling the thyroid gland," Bailliere's Clinical Endocrinology and Metabolism, vol. 5, no. 4, pp. 727-754, 1991.

[27] R. Parameswaran, S. Brooks, and G. P. Sadler, "Molecular pathogenesis of follicular cell derived thyroid cancers," International Journal of Surgery, vol. 8, no. 3, pp. 186-193, 2010.

[28] A. Porcellini, G. Fenzi, and E. V. Avvedimento, "Mutations of thyrotropin receptor gene," Journal of Molecular Medicine, vol. 75, no. 8, pp. 567-575, 1997.

[29] S. T. Sawyer and S. Cohen, "Enhancement of calcium uptake and phosphatidylinositol turnover by epidermal growth factor in A-431 cells," Biochemistry, vol. 20, no. 21, pp. 6280-6286, 1981.

[30] J. K. Shaver, S. Tezelman, A. E. Siperstein et al., "Thyroidstimulating hormone activates phospholipase $\mathrm{C}$ in normal and neoplastic thyroid tissue," Surgery, vol. 114, no. 6, pp. 10641069, 1993.

[31] M. J. Schlumberger, S. Filetti, and I. D. Hey, "Nontoxic goiter and thyroid neoplasia," in Williams Textbook of Endocrinology, H. M. Kronenberg, S. Melmed, K. S. Polonsky, and P. R. Larsen, Eds., pp. 411-442, Saunders, Philadelphia, Pa, USA, 11th edition, 2008.

[32] D. R. Clemmons, "Structural and functional analysis of insulin-like growth factors," British Medical Bulletin, vol. 45, no. 2, pp. 465-480, 1989.

[33] S. E. Hankinson, W. C. Willett, G. A. Colditz et al., "Circulating concentrations of insulin-like growth factor-I and risk of breast cancer," The Lancet, vol. 351, no. 9113, pp. 1393-1396, 1998.

[34] J. Ma, M. N. Pollak, E. Giovannucci et al., "Prospective study of colorectal cancer risk in men and plasma levels of insulin-like growth factor (IGF)-I and IGF-binding protein-3," Journal of the National Cancer Institute, vol. 91, no. 7, pp. 620-625, 1999.

[35] D. Tramontano, G. W. Cushing, A. C. Moses, and S. H. Ingbar, "Insulin-like growth factor-I stimulates the growth of rat thyroid cells in culture and synergized the stimulation of DNA synthesis induced by TSH and Graves'-IgG," Endocrinology, vol. 119, no. 2, pp. 940-942, 1986.

[36] M. A. Pisarev, "Interrelationships between the pancreas and the thyroid," Current Opinion in Endocrinology, Diabetes and Obesity, vol. 17, no. 5, pp. 437-439, 2010.

[37] A. Gursoy, "Rising thyroid cancer incidence in the world might be related to insulin resistance," Medical Hypotheses, vol. 74, no. 1, pp. 35-36, 2010.

[38] J. N. Rezzonico, M. Rezzonico, E. Pusiol, F. Pitoia, and H. Niepomniszcze, "Increased prevalence of insulin resistance in patients with differentiated thyroid carcinoma," Metabolic Syndrome and Related Disorders, vol. 7, no. 4, pp. 375-380, 2009.

[39] K. Boelaert, "The association between serum TSH concentration and thyroid cancer," Endocrine-Related Cancer, vol. 16, no. 4, pp. 1065-1072, 2009.

[40] M. R. Haymart, D. J. Repplinger, G. E. Leverson et al., "Higher serum thyroid stimulating hormone level in thyroid nodule patients is associated with greater risks of differentiated thyroid cancer and advanced tumor stage," The Journal of Clinical Endocrinology \& Metabolism, vol. 93, no. 3, pp. 809814, 2008.

[41] S. A. Polyzos, M. Kita, Z. Efstathiadou et al., "Serum thyrotropin concentration as a biochemical predictor of thyroid malignancy in patients presenting with thyroid nodules," Journal of Cancer Research and Clinical Oncology, vol. 134, no. 9, pp. 953-960, 2008. 
[42] M. Mouradian and N. Abourizk, "Diabetes mellitus and thyroid disease," Diabetes Care, vol. 6, no. 5, pp. 512-520, 1983.

[43] H. E. Tamez-Perez, E. Martinez, D. L. Quintanilla-Flores, A. L. Tamez-Peña, H. Gutiérrez-Hermosillo, and E. Díaz De LeónGonzález, "The rate of primary hypothyroidism in diabetic patients is greater than in the non-diabetic population. An observational study," Medicina Clinica, vol. 138, no. 11, pp. 475-477, 2012.

[44] C. Samanic, W. H. Chow, G. Gridley, B. Jarvholm, and J. F. Fraumeni, "Relation of body mass index to cancer risk in 362,552 Swedish men," Cancer Causes and Control, vol. 17, no. 7, pp. 901-909, 2006.

[45] D. G. Marrero, "The prevention of type 2 diabetes: an overview," Journal of Diabetes Science and Technology, vol. 3, no. 4, pp. 756-760, 2009.

[46] C. M. Kitahara, E. A. Platz, L. E. Freeman et al., "Obesity and thyroid cancer risk among U.S. men and women: a pooled analysis of five prospective studies," Cancer Epidemiology Biomarkers and Prevention, vol. 20, no. 3, pp. 464-472, 2011.

[47] A. G. Renehan, M. Tyson, M. Egger, R. F. Heller, and M. Zwahlen, "Body-mass index and incidence of cancer: a systematic review and meta-analysis of prospective observational studies," The Lancet, vol. 371, no. 9612, pp. 569-578, 2008.

[48] S. Uddin, P. Bavi, A. K. Siraj et al., "Leptin-R and its association with $\mathrm{PI} 3 \mathrm{~K} / \mathrm{AKT}$ signaling pathway in papillary thyroid carcinoma," Endocrine-Related Cancer, vol. 17, no. 1, pp. 191-202, 2010.

[49] C. J. Currie, C. D. Poole, and E. A. Gale, "The influence of glucose-lowering therapies on cancer risk in type 2 diabetes," Diabetologia, vol. 52, no. 9, pp. 1766-1777, 2009.

[50] G. Chen, S. Xu, K. Renko, and M. Derwahl, "Metformin inhibits growth of thyroid carcinoma cells, suppresses selfrenewal of derived cancer stem cells, and potentiates the effect of chemotherapeutic agents," The Journal of Clinical Endocrinology \& Metabolism, vol. 97, no. 4, pp. E510-E520, 2012.

[51] U. Smith and E. A. Gale, "Does diabetes therapy influence the risk of cancer?” Diabetologia, vol. 52, no. 9, pp. 1699-1708, 2009.

[52] S. L. Bowker, S. R. Majumdar, P. Veugelers, and J. A. Johnson, "Increased cancer-related mortality for patients with type 2 diabetes who use sulfonylureas or insulin," Diabetes Care, vol. 29, no. 2, pp. 254-258, 2006.

[53] Y. X. Yang, S. Hennessy, and J. D. Lewis, "Insulin therapy and colorectal cancer risk among type 2 diabetes mellitus patients," Gastroenterology, vol. 127, no. 4, pp. 1044-1050, 2004.

[54] L. B. Knudsen, L. W. Madsen, S. Andersen et al., "Glucagonlike peptide-1 receptor agonists activate rodent thyroid Ccells causing calcitonin release and C-cell proliferation," Endocrinology, vol. 151, no. 4, pp. 1473-1486, 2010.

[55] L. W. Madsen, J. A. Knauf, C. Gotfredsen et al., "GLP-1 receptor agonists and the thyroid: C-cell effects in mice are mediated via the GLP-1 receptor and not associated with RET activation," Endocrinology, vol. 153, no. 3, pp. 1538-1547, 2012.

[56] D. J. Drucker, S. I. Sherman, R. M. Bergenstal, and J. B. Buse, "The safety of incretin-based therapies-review of the scientific evidence," The Journal of Clinical Endocrinology \& Metabolism, vol. 96, no. 7, pp. 2027-2031, 2011.

[57] W. M. Wood, V. Sharma, K. T. Bauerle et al., "PPAR promotes growth and invasion of thyroid cancer cells," PPAR Research, vol. 2011, Article ID 171765, 11 pages, 2011.
[58] T. Stocks, K. Rapp, T. Bjorge et al., "Blood glucose and risk of incident and fatal cancer in the metabolic syndrome and cancer project (Me-Can): analysis of six prospective cohorts," PLoS Medicine, vol. 6, no. 12, Article ID e1000201, 2009.

[59] K. Rapp, J. Schroeder, J. Klenk et al., "Fasting blood glucose and cancer risk in a cohort of more than 140,000 adults in Austria," Diabetologia, vol. 49, no. 5, pp. 945-952, 2006.

[60] S. Cowey and R. W. Hardy, "The metabolic syndrome: a highrisk state for cancer?” American Journal of Pathology, vol. 169, no. 5, pp. 1505-1522, 2006.

[61] M. Almquist, D. Johansen, T. Bjorge et al., "Metabolic factors and risk of thyroid cancer in the metabolic syndrome and cancer project (Me-Can)," Cancer Causes and Control, vol. 22, no. 5, pp. 743-751, 2011.

[62] A. A. Tahrani, A. Ball, L. Shepherd, A. Rahim, A. F. Jones, and A. Bates, "The prevalence of vitamin D abnormalities in South Asians with type 2 diabetes mellitus in the UK," International Journal of Clinical Practice, vol. 64, no. 3, pp. 351-355, 2010.

[63] E. Giovannucci, "Vitamin D status and cancer incidence and mortality," Advances in Experimental Medicine and Biology, vol. 624, pp. 31-42, 2008. 


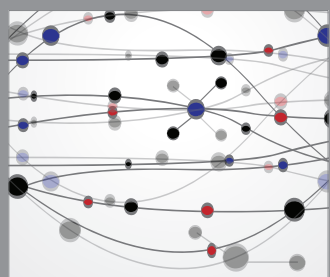

The Scientific World Journal
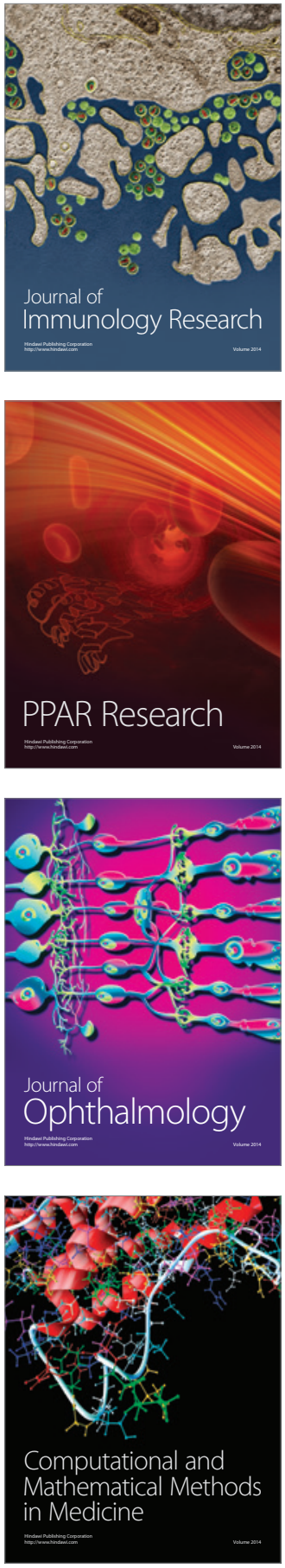

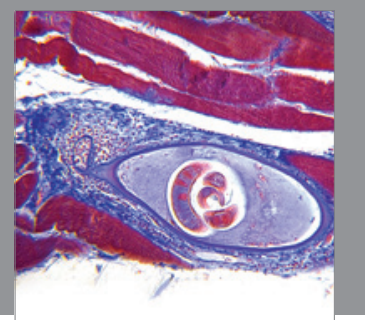

Gastroenterology

Research and Practice
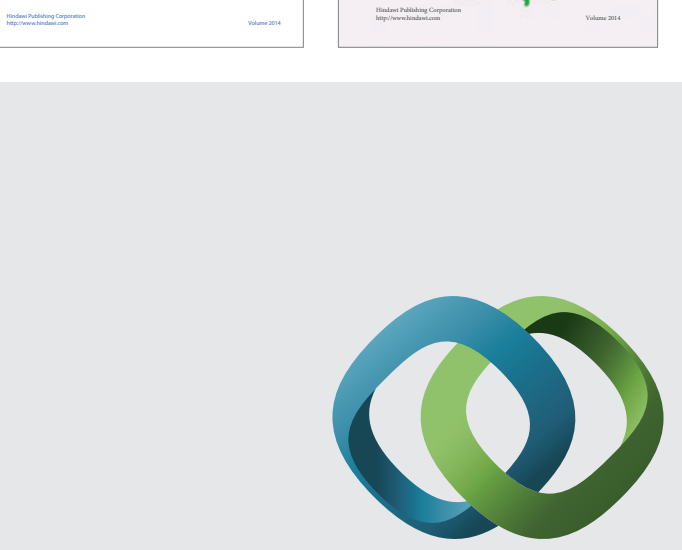

\section{Hindawi}

Submit your manuscripts at

http://www.hindawi.com
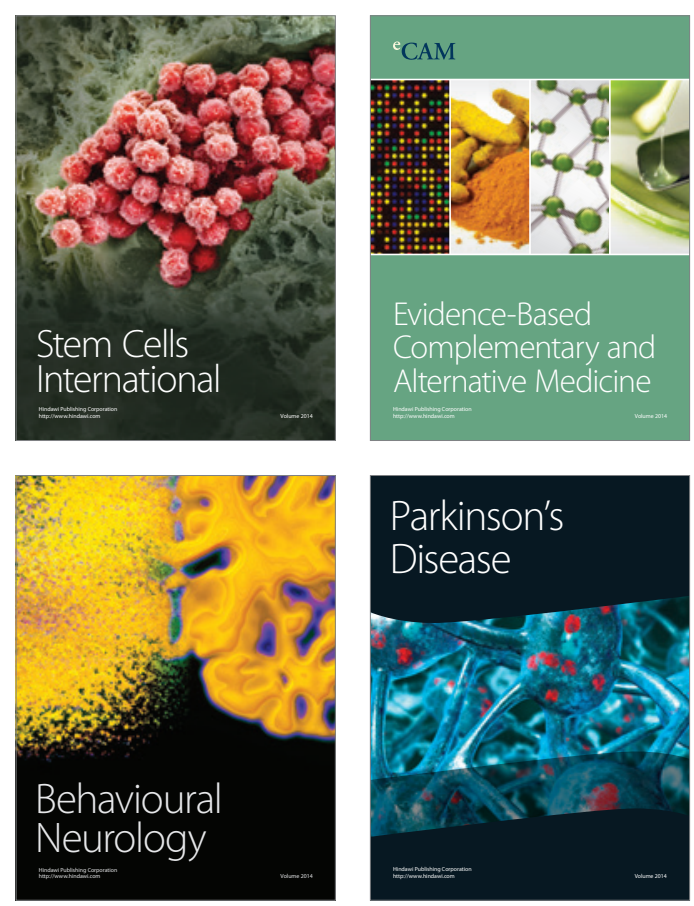

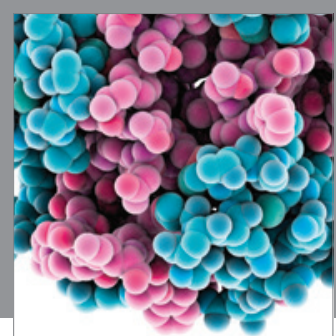

Journal of
Diabetes Research

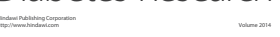

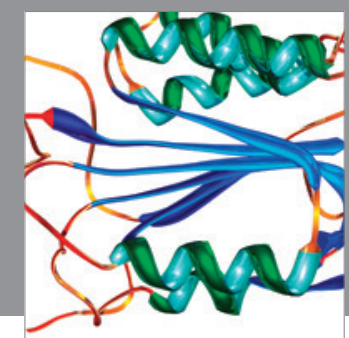

Disease Markers
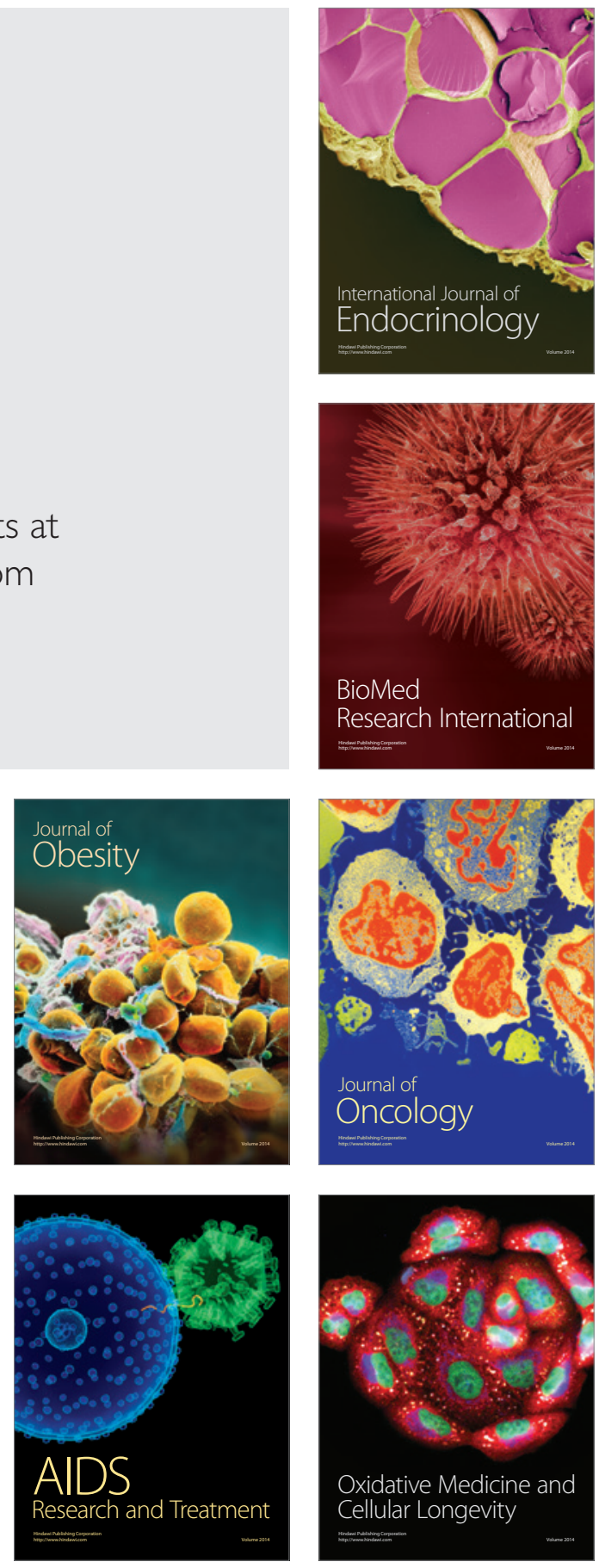